\title{
Changes in cultural ecosystems of a swidden society caused by the introduction of rubber plantations
}

\author{
Daisuke Terauchi* and Makoto Inoue \\ The University of Tokyo, Yayoi 1-1-1, Bunkyo-ku, Tokyo, Japan, 113-8657 \\ *Correspoinding author: Tel: +81 (0)3-5841-7508, Fax: +81 (0) 3-5841-5235, E-mail: aa087095@mail.ecc.u-tokyo.ac.jp
}

\begin{abstract}
This study aims to holistically examine the process of integration of rubber production into swidden society, based on observations of Benuaq Dayak society in East Kalimantan. Before the introduction of rubber production, villagers' livelihoods were based on swidden and rattan production, but household economies fared poorly owing to stagnating rattan prices. There was a high rate of rice self-sufficiency, while various work organization types and a collaborative work and profitsharing system played an important role in their livelihoods as a social safety net. The collaborative work and profit-sharing system was supported by a philosophy of mutual aid. After rubber production began, about half the villagers gave up swidden and the others switched to practicing swidden and rubber fields together. Their living standard was improved by cash income from rubber, and their rate of rice self-sufficiency dropped. A cash-income differential emerged among villagers, which caused social disruption such as arson and theft. The work organization was simplified from a collaborative work and profit-sharing system to an individual work and private-profit system. These livelihood changes and increasing cash income caused a social safety net malfunction, and impaired the philosophy of mutual aid.

It is inferred that the introduction of rubber production offers the possibility of both environmental and economic improvements, but to accomplish the well-balanced development of swidden society it is important to reconstruct and maintain the social ties that have been weakened by rising cash income and simplified types of work organization. It is also necessary to establish new institutional social networks for cooperation with the government to adapt to market economy conditions.
\end{abstract}

Keywords: Cultural ecosystems, swidden, rattan production, rubber production,

\section{INTRODUCTION}

East Kalimantan on Borneo Island is internationally renowned for rattan (Calamus spp) production. The Damai district in East Kalimantan is especially famous. Benuaq Dayak, the indigenous people of the Damai district, have traditionally practiced swidden for subsistence and cultivated rattan in the fallow season for cash income. This has been recognized as a sustainable production system in the sense of maintaining the long-

Table 1. Changes in commodity prices in Besiq.

\begin{tabular}{ccc}
\hline & Nov.1988 & Sept. 2007 \\
\hline Gasoline (Rp./L) & 700 & 7,000 \\
\hline Sugar (Rp./kg) & 1,000 & 8,000 \\
\hline Rice (Rp./kg) & 660 & 5,000 \\
\hline Rattan (Rp./kg) & $250-750$ & 800 \\
\hline $\begin{array}{c}\text { Exchange rate } \\
\text { (US\$1) }\end{array}$ & Rp.1,731 & Rp.9,104 \\
\hline
\end{tabular}

Sources: Field research and Inoue (1989) term cycle of swidden and generating cash income (Pambudhi 2004, Inoue 1990, Weinstock 1983).

However, rattan prices have recently been stagnating even though the prices of commodity goods are on the rise (Table 1). This is worsening the economy in the Damai district. The government has implemented some projects to improve this situation, resulting in Para rubber (Hevea brasiliensis) fields being expanded to replace rattan gardens ${ }^{(1)}$. How will the introduction of rubber production change the local environment and society?

It is said that although there has been widespread deforestation when mature forests are displaced by rubber fields (Hukao 2004, Angelsen 1995, Vincent and Hadi 1993), the rubber fields established by swiddeners in Indonesia and Malaysia are a kind of secondary forest in the sense of biodiversity and utilization of non-timber forest products such as fruit, firewood, and medicinal

\footnotetext{
(1) In November 2007, the price of rubber (gum) was Rp. 5,600/kg. The price of rattan was Rp. $900 / \mathrm{kg}$. Even if the rattan processing cost is included, the total price of rattan is Rp. 3,200/ $\mathrm{kg}$. There is a big difference between the price of rattan and rubber.
} 
plants. Therefore the impact of rubber fields on forest ecosystems is not great (Penot 2004, de Jong 2001, Gouyon et al. 1993). Rubber fields are established in a swidden cycle. Swiddeners can produce food in the first through third years, and after seven years they can derive cash income from harvesting rubber (gum) in the same fields. Thus they can use the land intensively and be compatible with both the subsistence and market economies (Penot 2004, de Jong 2001, Dove 1993, Gouyon et al. 1993, Barlow and Muharminto 1982, Pelzer 1978, Thomas 1965). It is clear that the system of swidden and rubber production is a useful technique given the current situation of swidden areas with increasing population density and a globalized market economy.

The system of swidden and rubber production can be appreciated in terms of environmental, technological, and economic benefits. But there are some problems. Disparity in wealth grows steadily larger as rubber fields expand in villages (Miyamoto 2006, Gouyon 1993). Swidden cycles become unsustainable due to involvement in the market economy (Inoue 1990). Swiddeners expand their rubber fields to mature forests in pursuit of personal profit (Hukao 2004) and to safeguard land rights which are threatened by external bodies such as the government and companies (Angelsen 1995, Gouyon 1993).

Bearing these facts in mind, this paper adopts a holistic approach in examining the changes in the local environment and society caused by the introduction of rubber production.

In recent papers on agroforestry systems, the introduction of new tree crops such as rubber and rattan in swidden systems has attracted researchers' attention as a method of developing swidden-based society while preserving the environment (Watanabe 2002, Sato 1999, Angelsen 1995, Hukui 1994). But there is no existing research which examines the process of integrating rubber production into their society.

The objective of this paper is to holistically examine the introduction of rubber production into Benuaq society and infer recommendations that will be of help in other places where new agroforestry systems are being introduced.

\section{MATERIALS AND METHODS}

\section{Analytical framework}

In order to holistically comprehend the process of change

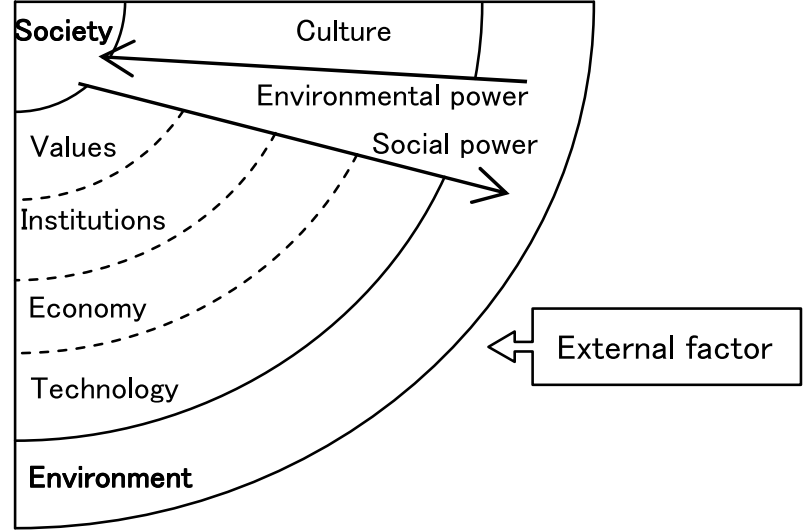

Fig. 1. Dynamics model of cultural ecosystems. Source: Inoue, 1995

in Benuaq society, we adopted the Òcultural ecosystem approachÓ (Inoue 1995) based on Òcultural ecosystemsÓ (Kawakita 1989) (Fig. 1). This approach divides the structure of an area into five sections: environment, technology, economy, institutions, and values. In addition, an external factor is added to some sections, and its impact extends to the other sections. In this research, the external factor is rubber production. In the technology section, the focus is on technologies of swidden, rattan, and rubber production, while in the economic section the focus is on cash income, and in the institutions section on work organization. Finally, in the values section the focus is on the villagers' thinking, especially with regard to types of work organization.

\section{Selection of study villages}

The Damai district is the main residence of the Benuaq people. We chose two research sites, one of which was more influenced by rubber production. These were compared to examine the process of change in Benuaq society. Betukng, a community in Besiq Village, was selected for being the less influenced community, and Keay Village was selected as the more influenced village. These were our main research sites. To discuss the future of cultural ecosystems, complementary research was conducted in Asa Village, Barong tongkok district, which is next to Damai district, where rubber production was introduced earlier than in Damai district ${ }^{(2)}$.

\footnotetext{
(2) Most residents in Asa Village are Tonyoi Dayak. Both Benuaq and Tonyoi are subgroups of the Luangan Dayak. They regard themselves as having almost the same livelihood and culture, such as swidden and rattan production and curative ceremonies. Thus the two villages and one community can be compared.
} 
Inoue (1989) conducted socio-economic research in Damai district in the late 1980s. In this research, the research sites selected were Besiq, which has a low population density and difficult access, and Jengan danum, which has a high population density and easy access. Betukng is part of Besiq Village, and Keay is located next to Jengan danum. Therefore the state of population density and physical access in Besiq and Keay in 2007 is similar to that of Besiq and Jengan danum in $1989^{(3)}$, thereby permitting comparison of research results about both ${ }^{(4)}$. Using the results of Inoue (1989), we can understand well the socioeconomic changes over a period of about 20 years.

\section{Data collection}

Field research was conducted over 10 months between August 2006 and May 2009. The main research was conducted over eight months between 2006 and 2007, followed up with complementary research conducted for two months in 2008 and 2009.

In Betukng, there were 19 households in 2007. Six households were chosen randomly from these to research their economic conditions and their working organization in the swiddens, We also conducted formal interviews with them.

In Keay, there were 181 households in 2007. Thirtyone households were chosen randomly from these to research their economic conditions. Of the total 31 households, 17 practiced swidden agriculture. Eight households were selected from among those 17 in 2007 to study the swidden working organization, and formal interviews were conducted with them.

In Asa, there were 4 RTs (Rukun Tetangga: neighborhoods in village) in 2008. RT1 was selected as representative of Asa, and 22 households were chosen randomly from 38 households within RT1. Formal interviews were conducted with them.

In addition, we also had complementary interviews with village chiefs, customary chiefs, and key persons with knowledge of the history and rubber project in all three villages. Participant observation was conducted to collect supplemental data. Cash income from rattan and rubber is derived by the following formulas: For rattan,

\footnotetext{
(3) The population densities of Besiq and Jengan danum in the late 1980s were 2.6 and 6.7 persons $/ \mathrm{km}^{2}$, respectively (Inoue 1989), and those of Besiq and Keay in 2007 were 2.6 and 9.9 person/ $\mathrm{km} 2$, respectively.

(4) The reason Jengan danum Village was not selected as a research site is that this village has been urbanized during the last 20 years. Many shops are lined up along the main road and a market is held twice a week. Therefore Keay Village was selected.
}

the amount of harvested rattan $(\mathrm{kg})$ in 2007 times the rattan price (Rp.800/kg) in September, 2007; for rubber, the amount of harvested rubber $(\mathrm{kg})$ per month times 12 months times the average rubber price $(\mathrm{Rp} .5,600 / \mathrm{kg})$ in $2007^{(5)}$. Information on rubber projects was collected from the Agricultural and Forestry Department in West Kutai prefecture.

\section{RESULTS AND DISCUSSION}

\section{Description of research sites \\ Damai district and three rubber projects}

The Damai district is located along the midstream portion of the Mahakam River in East Kalimantan province (Fig. 2). Because of its tropical rainy climate, it is ecologically part of the humid lowland tropics. There are no clearly distinguished rainy and dry seasons, but normally it is dry from May to September and rainy from October to April. The population of Damai district was 9,356 in 2007 and its population density is 5.3 person $/ \mathrm{km}^{2}$.

The rubber fields were expanded in West Kutai prefecture, to which Damai district belongs, by three government projects. PRPTE (Peremajaan, Rehabilitasi dan Perluasan Tanaman Ekspor) was implemented from $1978 / 79$ to $1982 / 83$ in the Barong tongkok district including Asa. TCSSP (Tree Crop Smallholder Sector Project) was implemented from 1992/93 to 2001 in Barong tongkok and some villages of the Damai district. RHL (Rehabilitasi Hutan dan Lahan) started in 2002 and continues in all districts of West Kutai prefecture (Fig. 2). Villagers can choose one of several tree crops in the three projects, but most villagers choose rubber trees.

The three projects were implemented so as to expand outwards from Sendawar, the central governmental city in West Kutai prefecture, to remote areas. It is clear that the influence of rubber production corresponds to the distance from Sendawar. Actually Keay, which is the closest of the Damai-district villages to

\footnotetext{
${ }^{(5)}$ When a collector buys rattan or rubber from a villager, the rattan or rubber is weighed by the collector in the villager's presence. Therefore villagers remember the approximate amount of harvested rattan or rubber in a year or a month. Rattan prices do not fluctuate very much, staying in the narrow range of Rp. $800 / \mathrm{kg}$ to Rp. $1,000 / \mathrm{kg}$ during the period of field research (between August 2006 and May 2009). As such, I adopted Rp. 800/kg in September 2007 when I conducted household economy interviews. On the other hand, rubber prices fluctuate much, ranging from Rp. 3,000/kg to Rp. 9,000/ kg during the field research period. I therefore calculated the average rubber price in 2007 using information on rubber prices in each month from a rubber collector in Keay. The average rubber price in 2007 was Rp. 5,600/kg.
} 

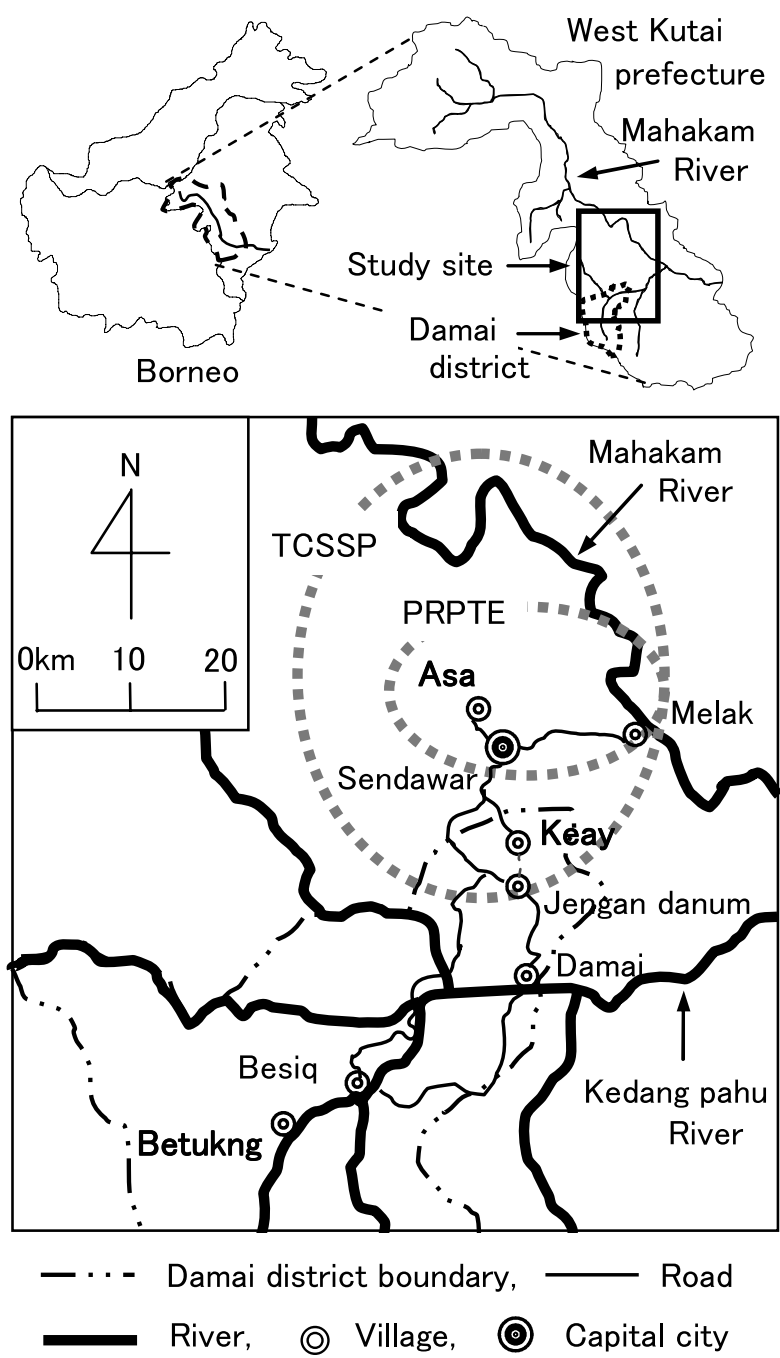

Note: The PRPTE and TCSSP areas are drawn on the basis of official documents. RHL is conducted in all districts of West Kutai prefecture.

Fig. 2. Location of study site.

Source: Prepared by Daisuke Terauchi

Sendawar, created the largest number of rubber fields under TCSSP in Damai district ${ }^{(6)}$. Besiq, which is located the farthest from Sendawar, has not implemented TCSSP. Until 2005, villagers in Keay established 210 ha of rubber fields under the RHL, while villagers in Besiq had 50 ha of rattan gardens but no rubber fields under the RHL.

(6) TCSSP was implemented in four villages in Damai district. The area of rubber fields in Keay is the largest, at 445 ha. The second-largest is Jengan danum, at 271 ha.

\section{Besiq and Betukng villages}

Besiq is the farthest up the Kedang pahu river, a tributary of the Mahakam river. In 2007 the population was 1,465 and there were 374 households. Its population density is 2.6 persons $/ \mathrm{km}^{2}$, which is lower than that of Damai district. The landscape around Besiq is old secondary forest, rattan gardens, and traditional fruit gardens. Mature forests still remain upriver of Besiq.

Betukng is upriver from Besiq. It had 19 households as of 2007. Betukng was officially established in 2003, but people have lived there since the 1970 s. Rubber trees were introduced in Betukng in 2005. Villagers have not yet harvested gum. Betukng is in the introductory phase of its rubber fields.

\section{Keay Village}

Keay is located along the road which connects Melak to Damai via Sendawar. In 2007 there were 765 people and 181 households. Population density is 9.9 person $/ \mathrm{km}^{2}$, excluding the national botanical garden $\left(50.0 \mathrm{~km}^{2}\right)$ where private uses such as swiddens, rattan, and rubber fields are prohibited for villagers. Keay's population density is higher than those of the Besiq and Damai districts. The landscape around Keay consists of young secondary forests, rubber fields, and traditional fruit gardens. Rubber fields were expanded by TCSSP from 1992 onwards and are now harvested for gum. After conclusion of TCSSP, villagers raised rubber fields themselves. There are no inherited rubber fields (Table 2). Keay is in the early stage of expansion.

\section{Asa Village}

Asa is located in Barong tongkok district. In 2007 it had 668 people and 173 households. Its population density is 26.0 person $/ \mathrm{km}^{2}$, the highest of the research sites. The landscape around Asa is mostly rubber fields, which were expanded by PRPTE and TCSSP. Some rubber fields

Table 2. Conditions of rubber fields in Keay and Asa.

\begin{tabular}{|c|c|c|c|c|c|}
\hline & \multirow{2}{*}{\multicolumn{2}{|c|}{$\begin{array}{c}\text { Keay }(\mathrm{N}=31) \\
\text { Harvesting }\end{array}$}} & \multirow{2}{*}{\multicolumn{2}{|c|}{$\begin{array}{l}\text { Asa }(\mathrm{N}=22) \\
\text { Harvesting }\end{array}$}} \\
\hline & & & & & \\
\hline & & Not yet & Yes & Not yet & Yes \\
\hline \multirow{4}{*}{$\begin{array}{c}\text { How } \\
\text { obtained } \\
(\%)\end{array}$} & Using projects & 9.0 & 25.4 & 1.7 & 17.9 \\
\hline & By oneself & 32.8 & 32.8 & 34.4 & 10.2 \\
\hline & Purchase $^{1}$ & 0.0 & 0.0 & 16.5 & 9.8 \\
\hline & Inheritance & 0.0 & 0.0 & 0.0 & 9.4 \\
\hline \multirow{2}{*}{\multicolumn{2}{|c|}{ Total }} & 41.8 & 58.2 & 52.6 & 47.4 \\
\hline & & \multicolumn{2}{|c|}{100.0 (61ha) } & \multicolumn{2}{|c|}{$100.0(117.15 \mathrm{ha}$} \\
\hline
\end{tabular}

Note1:This includes buying rubber fields and land for rubber fields. Source: Field research 
Table 3. The sequence of operations in swidden.

\begin{tabular}{|c|c|c|c|}
\hline Month & Name & Operation & Share of the work load \\
\hline \multirow{6}{*}{ May - Sept } & Nokap & : Cutting small trees & Men and Women \\
\hline & Noang & : Felling big trees & Men \\
\hline & Nutu Joa & : Removing branches of fallen trees & Men \\
\hline & Oikng Joa & : Drying trees in the sun & \\
\hline & Nyuru & : Burning trees & Men and Women \\
\hline & Mongkakng & : Re-burning some unburned trees & Men and Women \\
\hline Oct & Ngasak & : Dibble and sowing rice & Men and Women \\
\hline Oct - Jan & Ngejikut & : Weeding & Women \\
\hline Feb - Apr & Ngotapm & : Harvesting ripe rice & Men and Women \\
\hline
\end{tabular}

Source:Field research

were obtained by purchasing land, while others were inherited (Table 2). There is little land available to raise new rubber fields in Asa, which is in the latter stage of rubber field expansion.

\section{Findings and analysis}

First, the cultural ecosystems prior to the introduction of rubber production are assessed using data gained from field work and compared with findings from Inoue (1989). This phase was unable to clarify the villagers' thinking. After this we then investigate the characteristics of rubber production as an external factor, and then examine the changing of cultural ecosystems in the introduction phase (Betukng), early expansion stage (Keay), and latter expansion stage (Asa).

\section{Before the introduction of rubber production ${ }^{(7)}$ Technology}

We focus on the technology of swidden and rattan production as the main livelihood activity. Table 3 shows the sequence of operations in swidden. It is important to note that the sequence of operations from cutting (Nokap) to burning (Nyuru, Mongkakng) must be finished by the rainy season, but weeding operations are continued until harvesting. If not, a good rice harvest cannot be expected. Harvesting (Ngotapm) runs from late February through April. Usually villagers produce rice and some vegetables for themselves. In Besiq, villagers usually change their

\footnotetext{
(7) Data in the technology section and the work organization section are based on field research results. Data on economic conditions in the late 1980s are cited from Inoue (1989).
}

swidden sites every year. But in Keay, the same swidden site is used two, three, or sometimes even four times consecutively.

In rattan production, rattan seeds are planted after harvesting swidden or at the same time as sowing swidden. Villagers then weed around the rattan seedlings (Nokap). After the forest canopy has closed, they begin girdling big trees around rattan (Ngeleleng) so that the rattan gets nutrients and sunlight. Nokap and Ngeleleng are carried out irregularly and extensively. The first harvest is about eight years after planting (Pikat we), after which the rattan can be harvested from the same rattan stump every three years. During the harvesting operation, villagers cut the rattan up in the trees, then pull the rattan to the ground while slicing off the thorns. Then they cut the rattan into 6-m lengths and make bundles of 30-40 kg, which are then carried from the forest to the house of a rattan collector, who pays them in cash. Harvesting and carrying rattan are very hard and dangerous.

\section{Economy}

We can determine the state of annual cash income in Besiq and Jengan danum in the late 1980s from Table 4 and Table 7. There are three important points. First, the main source of cash income in both villages was rattan. Second, there is big difference in the total amount of cash income between Besiq and Jengan danum. Third, there are differences in the makeup of rattan-related cash income between Besiq and Jengan danum.

With regard to the second and third points, this difference was caused by the amount of available land and sizes of rattan gardens in the two villages. In Besiq, 
Table 4. Comparison of the cash income ratio of Besiq and Betukng.

\begin{tabular}{|c|c|c|c|c|}
\hline \multicolumn{3}{|c|}{ Annual cash income (\%) } & Late $1980 \mathrm{~s}$ & $2007(\mathrm{~N}=6)$ \\
\hline \multirow{6}{*}{$\begin{array}{l}\text { Agricultural } \\
\text { products }\end{array}$} & \multicolumn{2}{|c|}{ Rice } & 0.0 & 1.1 \\
\hline & \multicolumn{2}{|c|}{ Livestock } & 0.3 & 15.2 \\
\hline & \multicolumn{2}{|c|}{ Vegetables } & 0.0 & 2.2 \\
\hline & \multirow{2}{*}{ Rubber } & Own gardens & 0.0 & 0.0 \\
\hline & & Other's gardens & 0.0 & 0.0 \\
\hline & \multicolumn{2}{|c|}{ Total } & 0.3 & 18.5 \\
\hline \multirow{7}{*}{$\begin{array}{l}\text { Forest } \\
\text { products }\end{array}$} & \multirow{4}{*}{ Rattan } & Own gardens & 55.5 & 23.2 \\
\hline & & Other's gardens & 1.7 & 0.0 \\
\hline & & Scrubbing & 19.4 & 15.1 \\
\hline & & Total & 76.6 & 38.3 \\
\hline & \multicolumn{2}{|c|}{ Hunting } & 15.5 & 24.6 \\
\hline & \multicolumn{2}{|c|}{ Fruit } & 0.0 & 4.9 \\
\hline & \multicolumn{2}{|c|}{ Total } & 92.1 & 67.7 \\
\hline \multicolumn{3}{|c|}{ Others $^{1}$} & 7.6 & 13.8 \\
\hline \multicolumn{3}{|c|}{ Total } & 100.0 & 100.0 \\
\hline \multirow{2}{*}{\multicolumn{2}{|c|}{$\begin{array}{l}\text { Average annual } \\
\text { cash income }\end{array}$}} & $(\mathrm{Rp} .)^{2}$ & 784,149 & $4,541,333$ \\
\hline & & $(\mathrm{US} \$)^{3}$ & 453.0 & 498.8 \\
\hline
\end{tabular}

Note 1: The others in late 1980s include gold dust and in 2007 include carpentry and wages for surveying coal (temporary work at a coal mining company). Note 2: US\$1=Rp. 1,731in Nov 1988, US\$1=Rp. 9,104 in Sept, 2007

Note 3: Average annual cash income in US\$ is calculated with the exchange rate in 1988 and in 2007.

Source: Late 1980s data are edited from Inoue(1989). 2007 data are from field research.

Table.5. Work organization types in Benuaq society.

\begin{tabular}{lcl}
\hline & Local name & Description \\
\hline a) & Kerja Edotn & : Individual family labor system. Especially in sowing activities, it is called Sentutuk. \\
\hline b) & Pelo & : Labor exchange among households characterized by direct parity reciprocity. \\
\hline c) & Awaat & : A spontaneous offer of labor without compensation. \\
\hline d) & Perawaat & : An offer of labor based on request without asking for compensation. \\
\hline e) & Konokng & : A kind of traditional paid labor system in harvesting rice, where remuneration is the \\
\hline g) & Betusa' & amount of rice harvested from noon to evening. Usually the amount is $20-30$ kg. \\
\hline f) & Uenguli) & is usually $50 \%$ of total harvests. Some villagers call this wrok organization as "Menguli". \\
\hline h) & Sempakat & : A modern paid labor system. \\
\hline
\end{tabular}

Source: Field research

the population density was low while the rattan gardens per household were large in number and in size. On the other hand, in Jengan danum there was a high population density, land subdivision via inheritance is common, and the rattan gardens per household were few and small ${ }^{(8)}$. Therefore the total amount and the percentage of cash

\footnotetext{
${ }^{(8)}$ The average number and size of rattan gardens per household was 5.1 and 9.4 ha in Besiq, and 2.3 and 1.0 ha in Jengan danum, respectively (Inoue, 1989).
}

income derived from growing rattan in private gardens or rattan scrubbing were high in Besiq. In Jengan danum, on the other hand, total cash income was low and the percentage of cash income from rattan in garden owned by other people was high.

Another economic factor is rice self-sufficiency. The rate of rice self-sufficiency in 1989 was $61 \%$ in Besiq and $95 \%$ in Jengan danum. The reason this difference was that villagers in Besiq could buy rice using their cash income, but villagers in Jengan danum could not. 


\section{Work organization}

There are several types of work organization in Benuaq society. Table 5 gives the local names and descriptions of the work organization types. In swidden, Kerja Edotn, Pelo, Konokng, Awaat/Perawaat, are often adopted. Awaat/Perawaat, Upaah is also adopted in everyday life.

During rattan harvesting, Betusa' is adopted as well as individual family labor. If villagers do not have enough rattan gardens, they can ask to help other villagers harvest their rattan gardens. In Betusa' the harvested rattan is divided $50-50$ between owner and worker. The cash from Betusa' holds an important place in total income in Jengan danum (33.1\%).

During rattan processing, the village women scrub rattan (Gosok), which also provides an important (19.4\%) part of the total cash income in Besiq. This is the sole opportunity for paid labor for women.

\section{External factor: Introduction of rubber production}

TCSSP and RHL were implemented in Damai district. The rubber fields established by RHL had not yet been harvested when the main research was conducted in 2006 and 2007. Therefore we will treat TCSSP as an external factor to Benuaq society in this research.

TCSSP was implemented through cooperation between the Indonesian government and the Asian Development Bank (ADB). The purpose of TCSSP is to reduce poverty in rural communities and produce agricultural export products in non-productive areas. It is also expected to decrease swidden by introducing rubber production (ADB 2002). Villagers used 1 ha of their own land for rubber fields. TCSSP gave villagers technical support and advice for: 1) planting rubber seedlings at intervals of $4 \mathrm{~m}$ by $5 \mathrm{~m}$ (500 seedlings per ha), 2) managing rubber fields using fertilizer and agrochemicals (pesticides, herbicides, fungicides, and formic acid) ${ }^{(9)}$, and 3) intercropping with corn, soybeans, and other crops, except casaba and fruit trees, in rubber fields to reduce management costs and use land efficiently (DP 1994, ADB 2002). Villagers said they were advised by an assistant to tap rubber trees in the early morning.

The costs of land preparation, agricultural tools, and rubber seedlings were covered by a grant in the first year, while fertilizer, agrochemicals, and land maintenance

\footnotetext{
(9) $\mathrm{ADB}$ (2002) estimates of the annual amounts of fertilizer and agrochemicals for rubber trees were $250 \mathrm{~kg}$ and $42 \mathrm{~L}$ per ha, respectively. $\mathrm{ADB}$ also recommends their use on intercrops, although the amount varies.
}

costs were covered by credit from the first to the sixth years, which is the immature stage of rubber trees. In seventh year, the number of rubber trees that could be harvested was checked, and the rate of repayment was decided by a formula which divides the number of rubber trees which can be harvested by 375 . If more than 375 of 500 rubber trees/ha in a rubber field can be harvested, it is deemed possible for villagers with that rubber field to repay credit $100 \%$. If villagers have failed in raising a rubber field, they do not need to repay. The term of credit repayment runs from the seventh to the 12th year in the five-year project plan. But according to ADB (2002), repayment of credit was stagnating due to the poorly designed credit-recording system, scheduling of payments, and collection procedure. Overall, debt repayment rate is only $3.1 \%$. According to the head of the prefectural agricultural department, the debt repayment rate is $15-20 \%$ in West Kutai prefecture. Most villagers do not repay loans and do not even know how.

Judging from this situation, the external factor in the technology section of cultural ecosystems is rubber plantation techniques, which is characterized by using fertilizers and agrochemicals, while the external factor in the economy section is credit, but as the external factor we treat only rubber plantation techniques because the rate of repayment considered to be determined by the rubber tree survival rate. And in fact the loan repayment system is not functioning.

The scheme of PRPTE is the same as that of TCSSP, which is known as a Òfull approachÓ project with full credits and support during the immature stage of rubber (Penot 2004). Thus we can forecast the future of Benuaq society by examining the situation in Asa, where PRPTE was implemented. Villagers in Besiq and Betukng acquired information on TCSSP from networks of relatives and from observing rubber fields in other villages.

\section{Introductory phase: Betukng (Besiq). Technology}

Villagers in Betukng have been planting rubber trees since 2005. Villagers can get rubber seeds from their own traditional fruit gardens. Otherwise, they ask other people for rubber seeds.

Villagers in Betukng plant rubber seedlings or seeds after the burn-off or harvest of swidden. They plant seedlings or seeds in rows, the preferred planting method for rubber projects. They use no fertilizer or agrochemicals because these are unaffordable, and they 
leave, or sometimes plant anew, useful trees such as fruit trees and wood species in rubber fields, although they learn from rubber projects that it is better for rubber trees to clear all competing vegetation. Almost all villagers use old secondary forests for swidden, and shift swiddens every year; thus intercropping techniques which use the same fields for several years to manage rubber trees are not adopted, accordingly old secondary forests are cut to establish rubber field every year.

Rubber fields need more intensive management than rattan gardens. Therefore it is hard for villagers to cope with both tending swidden and managing rubber fields intensively. If they allocate labor to manage rubber fields intensively or intercrop and make swidden on the same land for several years, they cannot expect a substantial return from the swidden in that year. The lack of rice from swidden is a critical problem for them given the recent economic situation.

Some villagers failed in their attempt to raise rubber fields because they are not used to such intensive management, and because rubber seedlings were damaged by wild animals such as deer. There are no such problems with rattan gardens. Villagers cope with this problem by laying a lot of traps called Sekokoi around rubber fields. But this problem has not been solved yet.

\section{Economy}

Table 4 shows a comparison between the ratio of cash income in Besiq in the late 1980s and Betukng in 2007. The important points to note are that 1) the ratio of cash income from rattan is decreasing, but cash income from other sources is increasing, 2) economic conditions have not improved.

Villagers have not yet harvested rubber (gum). They are deliberately looking for other jobs to raise cash income, such as selling meat from wild animals, and paid labor in Besiq. Harvesting rattan is avoided because of the low price of rattan and the hard and dangerous nature of rattan harvesting operations.

The cash income situation saw scant improvement from the late 1980 s to 2007 . There was not much of a differential in annual average cash income among households, with the maximum cash income being Rp. 7.6 million per year, and the minimum cash income being Rp. 2.15 million per year. So almost all villagers were struggling to look for cash income. Usually villagers raise livestock such as pigs, chickens, and buffaloes to sell as an additional source of income in an emergency, or for sacrificial use and meals for participants in traditional
Table 6. Swidden work organization types at Betukng $(\mathrm{N}=6)(\%)$.

\begin{tabular}{ccccccc}
\hline & Cutting & Felling & Burning & Sowing & Weeding & Harvesting \\
\hline Edotn & 40.0 & 69.2 & 100.0 & 14.2 & 100.0 & 49.4 \\
Pelo & 60.0 & 30.8 & 0.0 & 85.8 & 0.0 & $50.6^{1}$ \\
Upaah & 0.0 & 0.0 & 0.0 & 0.0 & 0.0 & 0.0 \\
\hline Total & 100.0 & 100.0 & 100.0 & 100.0 & 100.0 & 100.0 \\
\hline
\end{tabular}

Note1: Konokng labor includes Pelo.

Source: Field research

ceremonies, rather than to eat on a daily basis. The fact that the percentage of livestock in their total cash income is high (15.1\%) indicates that they face serious livelihood difficulties.

Another important economic indicator is the rate of rice self-sufficiency, which increased from $61 \%$ in 1989 to $93.4 \%$ in 2007 . This implies that villagers lack enough money to buy rice. The monetary value of rice in 2007 is about Rp. 5,750,000 per household ${ }^{(10)}$.

\section{Work organization and values}

This section explains the types of work organization in swidden, rattan production, and hunting, as well as the villagers' philosophy of work organization.

Table 6 shows the ratio of the amount of labor per household in swidden allocated to each type of organization for each operation ${ }^{(11)}$. Mainly they adopt Kerja Edotn in burning and weeding, and Pelo in cutting, sowing, and harvesting ${ }^{(12)}$. Villagers can share labor and maintain the pace of swidden operation among villagers by Pelo, which decrease the possibility that somebody drop out. Basically the member of Pelo exchange labor with direct parity reciprocity, but sometimes the member of Pelo gives labor force more until finishing swidden operation. And the member of Pelo not only exchange labor, but also exchange or give materials to making swidden such as rice for sowing. So the member of Pelo has common sense that the member of Pelo has to help each other until finishing swidden operations in their swiddens. Upaah is not adopted. The total amount of harvested rice per household in 2008 averaged $1617 \mathrm{~kg}$ before milling. The average amount of rice exchanged per remuneration via Konokng is $333 \mathrm{~kg}$ out of $1617 \mathrm{~kg}$. Both cases exist in Konokng; in the former, swidden owners ask villagers to help harvesting to reduce heavy

\footnotetext{
${ }^{(10)}$ The monetary value of rice is calculated by the average amount of rice per household times the price of rice in each village.

(11) Kerja Edotn, Pelo and Upaah are chosen as the main type of work organization for swidden. In this paper Konokng is included in Pelo in harvesting because sometimes Konokng is mixed with Pelo in harvesting because people work and are paid on per-field and per-day bases.

${ }^{(12)}$ Awaat and Perawaat are often adopted in swidden burning.
} 
labor and to finish during the harvest season. If the harvest season has passed, villagers cannot harvest rice because of rice plant blowdown, and rice does not taste well when it is harvested too late. In the latter, workers ask owners for Konokng opportunities. Usually workers whose rice crops failed or who do not expect sufficient return on their own rice ask for Konokng. Therefore if an owner or worker refuses a request for Konokng, a person who was turned down will have serious livelihood challenges. It is therefore difficult for owners and workers to refuse requests for Konokng. Judging from these facts, the relationship between owners and workers is characterized by interdependence and based on a philosophy of mutual aid.

Betusa' is not adopted in Betukng, apparently because villagers can derive cash income from their own rattan gardens. According to research results on Betusa, in Besiq, there are no strict terms of employment regarding working times or the amount of harvests in Betusa'. But usually the number of Betusa' workers ranges from one to 20 at any one time. Harvesting periods ranged from several days to a month and the amount of harvested rattan is several hundreds on average. Both cases exist in Betusa' as in Konokng: in the former, owners ask villagers to help with harvests. In the latter, workers ask owners for Betusa' work. In the both cases, the reason an owner or worker asks for Betusa' is that he needs money urgently or in a substantial amount or there is no way to get cash income except asking for Betusa'. For example, when a family member is sick or when there is a wedding or funeral, villagers often depend on Betusa'. If an owner or worker is aware of these circumstances, it is difficult for him to refuse a Betusa' request. Judging from these facts, the relationship between owners and workers is characterized by interdependence and based on a philosophy of mutual aid.

Gosok is another common system. All women can be hired for Rp. 150/kg by rattan collectors. There are no formal terms of employment. The cash income from Gosok plays an important role in total cash income (Table 5). It is possible to raise cash income effectively with husband and wife working separately.

In terms of hunting practices, it was often observed that villagers went to hunt wild pigs and deer together. Usually the animals are divided equally among workers even if the labor and contribution to the hunt differs among workers ${ }^{(13)}$. The animals are then eaten or sold for cash income. The cash income from hunting plays an important role in total cash income (Table 5).
Table 7. Percentage of households which abandoned swidden in Keay $(\mathrm{N}=31)$.

\begin{tabular}{ccc}
\hline 2005 & 2006 & 2007 \\
\hline $61.3 \%(19)$ & $48.4 \%(15)$ & $45.2 \%(14)$ \\
\hline
\end{tabular}

Source: Field research

It is said that the model person in Benuaq society has thoughtful and sympathetic feelings, known as Terasi in Benuaq, and give things to other people or do good deeds voluntarily, which called sawai. If a person accepts sawai from someone, he must return sawai to them. If he does not do so, the villager is recognized as mean (perikat), and is thus ineligible for further sawai. Ideally, when dividing and sharing things among villagers, the split should be in equal parts. Villagers cannot refuse Konokng or Betusa' and also divide hunting profits equally among workers based on the villagers' philosophy of mutual aid as described above.

Judging from these facts, it was inferred that Pelo, Konokng, Betusa', Gosok and cooperative hunting tasks (referred to below as Òcollaborative workÓ) play a role as a social safety net for the villagers' livelihood. The relationship among villagers is characterized by interdependence and based on a philosophy of mutual aid.

\section{Early stage of expanding phase: Keay Village Technology}

About half the villagers do not practice swidden (Table 7) ${ }^{(14)}$. Their reasons are, first, that they could buy rice and second that swidden is hard work with few rewards.

The purpose of swidden changed from growing rice to cultivating rubber fields. Slash and burn tasks are intended to prepare land for rice and rubber fields, followed by planting rubber seedlings as well as rice and some vegetables. After harvesting rice in the first year, villagers practice swidden on the same land and also open new land. In the second year, slash and burn are intended to clear undergrowth from around rubber seedlings that were planted the previous year. Then rice are planted and rubber seedlings replanted accordingly. Usually villagers use the same plots of land for three years. Once it appears that the rubber trees have gained a strong enough foothold to withstand competition from wild plants and other trees, villagers leave the plot to itself and move on

\footnotetext{
${ }^{(13)}$ We observed that one young and one elderly villager went fishing together and the catch was divided equally, even though the young villager did more of the fishing.

${ }^{(14)}$ One villager discontinued swidden eight years ago.
} 
Table 8. Comparison of cash income ratio of Jengan danum and Keay.

\begin{tabular}{|c|c|c|c|c|c|c|c|}
\hline \multirow{2}{*}{\multicolumn{3}{|c|}{ Annual cash income $(\%)$}} & Late $1980 \mathrm{~s}$ & \multicolumn{4}{|c|}{2007} \\
\hline & & & Total & Total $(\mathrm{N}=31)$ & $\operatorname{Low}(\mathrm{N}=10)$ & Middle $(\mathrm{N}=15)$ & $\operatorname{High}(N=6)$ \\
\hline \multirow{7}{*}{$\begin{array}{l}\text { Agricultural } \\
\text { products }\end{array}$} & \multicolumn{2}{|c|}{ Rice } & 0.0 & 0.0 & 0.0 & 0.0 & 0.0 \\
\hline & \multicolumn{2}{|c|}{ Livestock } & 8.5 & 2.1 & 8.7 & 2.3 & 0.3 \\
\hline & \multicolumn{2}{|c|}{ Vegetables } & 0.0 & 0.4 & 0.2 & 0.7 & 0.0 \\
\hline & \multirow{3}{*}{ Rubber } & Own gardens & 0.0 & 54.2 & 54.4 & 66.4 & 41.3 \\
\hline & & Other's gardens & 0.0 & 10.4 & 23.0 & 4.8 & 13.4 \\
\hline & & Total & 0.0 & 64.6 & 77.4 & 71.2 & 54.7 \\
\hline & \multicolumn{2}{|c|}{ Total } & 8.5 & 67.1 & 86.3 & 74.2 & 55.0 \\
\hline \multirow{7}{*}{$\begin{array}{l}\text { Forest } \\
\text { products }\end{array}$} & \multirow{4}{*}{ Rattan } & Own gardens & 48.4 & 0.0 & 0.0 & 0.0 & 0.0 \\
\hline & & Other's gardens & 33.1 & 0.1 & 0.6 & 0.0 & 0.0 \\
\hline & & Scrubbing & 3.0 & 0.9 & 0.7 & 1.8 & 0.0 \\
\hline & & Total & 84.5 & 1.0 & 1.3 & 1.8 & 0.0 \\
\hline & \multicolumn{2}{|c|}{ Hunting } & 0.4 & 0.0 & 0.8 & 0.1 & 0.0 \\
\hline & \multicolumn{2}{|c|}{ Fruit } & 0.0 & 1.9 & 3.8 & 1.6 & 1.8 \\
\hline & \multicolumn{2}{|c|}{ Total } & 84.9 & 2.9 & 6.0 & 3.5 & 1.8 \\
\hline \multirow{3}{*}{ Others } & \multicolumn{2}{|c|}{ Sand $^{1}$} & 0.0 & 12.8 & 3.0 & 7.2 & 21.0 \\
\hline & \multicolumn{2}{|c|}{ Officer } & 0.0 & 7.9 & 0.0 & 6.3 & 11.5 \\
\hline & \multicolumn{2}{|c|}{ Others $^{2}$} & 6.5 & 9.3 & 4.7 & 8.9 & 10.8 \\
\hline \multicolumn{3}{|c|}{ Total } & 100.0 & 100.0 & 100.0 & 100.0 & 100.0 \\
\hline \multirow{2}{*}{\multicolumn{2}{|c|}{$\begin{array}{l}\text { Average annual } \\
\text { cash income }\end{array}$}} & $(\mathrm{Rp} .)^{3}$ & 200,484 & $18,998,726$ & $6,001,400$ & $18,159,633$ & $42,758,667$ \\
\hline & & $(\mathrm{USS})^{4}$ & 115.8 & $2,086.9$ & 659.2 & $1,994.7$ & $4,696.7$ \\
\hline
\end{tabular}

Note 1: There is quarry company whose trucks pick up sand collected by villagers from their land.

Note 2: Others in the late 1980s include furniture; in 2007 they include carpentry, security guards in the botanical gardens, carving agricultural tools, repairing cars and motorbikes, wages from the quarry company and coal mining company, teaching, and retail clerks.

Note 3: US\$1=Rp.1,731in Nov. 1988, US\$1=Rp. 9,104 in Sept. 2007.

Note 4: The average annual cash income in US\$ is calculated using exchange rates in 1988 and 2007.

Source: Data in the late 1980s are edited from Inoue (1989); data for 2007 are from field research.

to a different area. Villagers do not need to manage rubber fields intensively from this time on, so they just wait until harvesting is possible when the rubber trees are seven years old. What is important for shifting fields is not the amount of rice harvested, but the extent of rubber trees grown. Villagers regard rice production as a concomitant of raising rubber fields. Some villagers are eager to practice swidden to raise rubber fields, although about half the villagers have discontinued it. Rubber fields are also established on degraded land such as that overgrown with alang alang (Imperata cylindrica) caused by wildfires ${ }^{(15)}$.

Villagers in Keay followed technical advice and partially included the support of TCSSP in their practices for these purposes: 1) Plant 500 seedlings per ha with seedling intervals of $4 \mathrm{~m}$ by $5 \mathrm{~m}$. 2) Villagers who participated in TCSSP have used fertilizers and agrochemicals for the first six years. After six years or after villagers had started tending to the rubber fields

\footnotetext{
${ }^{(15)}$ Wildfires occurred in 1997, 1999, 2001, and 2004 around Keay.
}

Table 9. Annual expenditures in Keay $(\mathrm{N}=31)$.

\begin{tabular}{|c|c|c|}
\hline \multirow{6}{*}{ Food } & Rice & 19.4 \\
\hline & Fish & 12.6 \\
\hline & Meat & 2.6 \\
\hline & Vegetables & 6.1 \\
\hline & Seasoning & 12.3 \\
\hline & Others ${ }^{1}$ & 5.7 \\
\hline \multirow{2}{*}{$\begin{array}{c}\text { Daily } \\
\text { necessities }\end{array}$} & Gasoline & 25.6 \\
\hline & Others $^{2}$ & 4.8 \\
\hline \multirow{4}{*}{ Rubber } & Pesticide & 0.3 \\
\hline & Fertilizer & 0.4 \\
\hline & Herbicide & 0.6 \\
\hline & Tools & 0.1 \\
\hline \multicolumn{2}{|c|}{ Others $^{3}$} & 9.5 \\
\hline \multicolumn{2}{|c|}{ Total (\%) } & 100.0 \\
\hline \multirow{2}{*}{$\begin{array}{c}\text { Total cash } \\
\text { expenditures }\end{array}$} & (Rp.) & $12,096,583$ \\
\hline & $(\mathrm{USS})^{4}$ & 1,329 \\
\hline
\end{tabular}

Note1: Confectioneries, noodles and canned foods.

Note2: Clothing, dishes and kerosene.

Note3: Education costs, medical costs, baby goods, motorbikes, eating at small restaurants.

Note 4: US\$1=Rp.9,104

Source: Field research

themselves without assistance, most of the villagers did not use fertilizer or agrochemicals to manage their 
Table 10. Swidden work organization types in Keay (\%).

\begin{tabular}{|c|c|c|c|c|c|c|c|}
\hline & & Cutting & Felling & Burning & Sowing & Weeding & Harvesting \\
\hline \multirow{4}{*}{ All $(\mathrm{N}=8)$} & Edotn & 53.4 & 51.4 & 45.5 & 0.4 & 49.1 & 47.4 \\
\hline & Pelo & 26.4 & 42.8 & 54.5 & 99.6 & 30.4 & 33.1 \\
\hline & Upaah & 20.3 & 5.8 & 0.0 & 0.0 & 20.5 & 19.5 \\
\hline & Total & 100.0 & 100.0 & 100.0 & 100.0 & 100.0 & 100.0 \\
\hline \multirow{4}{*}{$\begin{array}{l}\text { Low- } \\
\text { income } \\
\text { group } \\
(\mathrm{N}=1)\end{array}$} & Edotn & 28.6 & 58.3 & 100.0 & 0.0 & 100.0 & 85.7 \\
\hline & Pelo & 28.6 & 0.0 & 0.0 & 100.0 & 0.0 & 14.3 \\
\hline & Upaah & $(+) 42.8$ & $(+) 41.7$ & 0.0 & 0.0 & 0.0 & 0.0 \\
\hline & Total & 100.0 & 100.0 & 100.0 & 00.0 & 100.0 & 100.0 \\
\hline \multirow{4}{*}{$\begin{array}{l}\text { Middle- } \\
\text { income } \\
\text { group } \\
(\mathrm{N}=4)\end{array}$} & Edotn & 73.3 & 40.6 & 29.4 & 1.2 & 73.1 & 45.5 \\
\hline & Pelo & 20.0 & 59.4 & 70.6 & 98.8 & 26.9 & 54.5 \\
\hline & Upaah & $(-) 6.7$ & 0.0 & 0.0 & 0.0 & 0.0 & 0.0 \\
\hline & Total & 100.0 & 100.0 & 100.0 & 100.0 & 100.0 & 100.0 \\
\hline \multirow{4}{*}{$\begin{array}{l}\text { High- } \\
\text { income } \\
\text { group } \\
(\mathrm{N}=3)\end{array}$} & Edotn & 36.8 & 70.8 & 100.0 & 0.0 & 19.0 & 45.7 \\
\hline & Pelo & 36.8 & 29.2 & 0.0 & 100.0 & 39.2 & 17.3 \\
\hline & Upaah & $(-) 26.4$ & 0.0 & 0.0 & 0.0 & $(-) 41.8$ & $(-) 37.0$ \\
\hline & Total & 100.0 & 100.0 & 100.0 & 100.0 & 100.0 & 100.0 \\
\hline
\end{tabular}

Note: In Upaah, the amount of labor provided is shown by (+) and the amount of labor received is shown by (-).

Source: Field research

rubber fields. Table 9 indicates that expenditures for fertilizer and agrochemicals are a small part of the total ${ }^{(16)}$. 3) Villagers adapted easily to intercropping for several years on the same land, even though they didn't use fertilizer and agrochemicals. This is because they usually grow rice two or three times in the same field. Some villagers plant fruit trees and cassava for their usefulness, although TCSSP technical guidelines forbid their planting. Villagers tap rubber trees early in the morning.

There are also some outstanding issues. RT4 reader said that around $25 \%$ of TCSSP participants in Keay could not successfully raise rubber fields because they were not used to intensive management as in Betukng, and that many villagers lost rubber fields due to wildfires.

\section{Economy}

Table 8 shows compares the cash income per household between Jengan danum in the late 1980s and Keay in 2007. The main changes are 1) increasing average annual cash income, and 2) increasing ratio of cash income from rubber (64.6\%) and decreasing ratio of cash income from rattan $(1.0 \%)$.

The living standard in Keay has improved due to

\footnotetext{
(16) The average price of fertilizer and agrochemicals in Keay in 2007 was US\$15.6, although the appraised average cost of fertilizer and agrochemicals as credit in 2002 was US\$96.1 (ADB, 2002).
}

cash income from rubber. The average annual cash income in the late 1980s was around $\$ 115.8$ while in 2007 it was around 18 times that, or $\$ 2,086.9$. Most households have their own motorbikes and buy foodstuffs. The rice self-sufficiency rate is $25.5 \%{ }^{(17)}$. The monetary value of rice was only about Rp. 550,000 per household in 2007. Villagers in Keay practice swidden agriculture in one plot for a few years as mentioned above even if their rice harvest decline. It does not matter to them because they already get enough cash incomes from rubber to buy rice. Compared with Betukng's situation, it appears there is a differential in annual average cash income among households, with the maximum cash income being Rp. 57.0 million per year, and the minimum cash income being Rp. 2.4 million per year.

Table 9 shows the ratios of annual cash incomes in low-, middle-, and high-income household groups. Certain characteristics will be identified in each group.

The low-income group consists of 10 households. A characteristic of this group is that the average size of their rubber fields is 0.7 ha, which are already being harvested. This is the lowest among the three groups. Factors explaining the lack of sufficient rubber fields are that villagers are new households, immigrants, and households who have lost rubber fields through fire.

\footnotetext{
(17) One villager said that Òvillagers eat rubber,Ó which means that villagers eat food purchased with cash income derived from rubber.
} 
Betusa' plays an important role in their total cash income ${ }^{(18)}$, but only for three households. There are not enough rubber fields to for Betusa' in Keay, and unlike rattan harvesting, rubber harvests do not need much labor.

The middle-income group consists of 15 households. The average size of their rubber fields is $1.4 \mathrm{ha}$. They succeeded in raising rubber field by TCSSP or themselves. Almost all villagers in this group derived annual cash income from rubber.

The high-income group consists of 6 households. The average size of their rubber fields is 1.2 ha. There are two types of households: one combines rubber tapping with other sources of cash income such as selling sand or serving in public office, while the other taps and manages rubber fields diligently ${ }^{(19)}$. Tapping rubber is usually carried out in the early morning. The tapping operation is straightforward enough for women and children to perform, and therefore households can combine tapping with other jobs.

\section{Work organization and values}

Table10 shows how each household allocates the labor to each type of work organization in each swidden operation in 2007. Upaah includes both the receiving and provision of labor by a household. We can see that Kerja Edotn and Pelo are basically adopted in all operations as in Betukng ${ }^{(20)}$. The total amount of rice harvested per household in 2008 was an average of $389 \mathrm{~kg}$ before milling. The extent of giving and receiving in rice from swidden due to Konokng remuneration averaged $84 \mathrm{~kg}$. But the number of households which practice swidden is decreasing. Thus opportunities for Pelo and Konokng among villagers are likewise decreasing. A recent phenomenon has seen villagers begin to adopt Upaah. Low-income households provide labor, which is received by the high income households as Upaah.

In rubber harvesting, Betusa' is also adopted. The system of Betusa' in rubber is similar to that in rattan. There are no specific terms of employment. Usually workers take charge of 1 ha, and the harvest period ranges from several months to several years. The harvest is divided half and half between owner and worker. Betusa' in Keay is adopted occasionally, and only between

\footnotetext{
${ }^{(18)}$ One householder went to another village along the Kedang pahu River to use Betusa' in his relatives' rattan gardens.

(19) Some households tap relative's rubber fields using Betusa' as well as their own rubber fields.

${ }^{(20)}$ Some villagers in Keay adopted Pelo for burning and weeding in 2007. But it is rare that Pelo is adopted for those tasks under Benuaq custom.
}

Table 11.The percentage of households which abandoned swidden in Asa $(\mathrm{N}=22)$.

\begin{tabular}{ccc}
\hline 2005 & 2006 & 2007 \\
\hline $59.1 \%(13)$ & $40.9 \%(9)$ & $50.0 \%(11)$ \\
\hline Source: Field research & &
\end{tabular}

relatives because there are not enough rubber fields in Keay and rubber harvests is easily accomplished by individual family labor with no need to hire additional workers.

In addition, there is no rubber processing work similar to Gosok in the village, and hence no need to hire women. Further, hunting is only rarely conducted in Keay, with fish and meat usually bought.

The villagers' swidden outlook is changing, with results showing that if they have enough money they use Upaah instead of Pelo because they prefer to finish fast and easily. If villagers adopt Pelo, they must work in all the members' swiddens on the same working days. During that time, they cannot harvest gum or rest when they want. Villagers recognized Upaah in swidden operations positively that swidden owner give working opportunity and money for workers and worker give labor, such as Betusa' and Konokng ${ }^{(21)}$. On the other hand, they also recognized Upaah negatively because only rich villager can use Upaah to finish swidden operation, and doesn't need to pay attention to workers' swidden situation. There are some villagers who complain against Upaah due to these reasons.

Judging from these results, opportunities for individual family labor such as tapping rubber trees and Upaah increase. On the other hand, there is less collaborative work due to the decrease in swidden, the shift from rattan to rubber production, and the increase in cash income. We therefore inferred that the capacity of a social safety net in the form of collaborative work is limited and dysfunctional in Keay. Also, increasing cash income has caused a change from Pelo to Upaah, showing that interdependent relationships have been broken and the philosophy of mutual aid weakened.

Other related factors include arson on rubber fields and stealing of gum, even among relatives. Elders told us how villagers with feelings of unfairness and jealousy were prone to arson and stealing. Prior to the introduction of rubber production there was no big cash income differential among villagers, and arson and stealing were

\footnotetext{
(21) Low-income households earned Rp. 1,000,000 by using Upaah in swiddens. On the other hand, the high-cash-income households spend an average of about Rp. 1,160,000 on Upaah in 2007.
} 
Table 12. Distribution of rubber field ownership.

\begin{tabular}{ccccc}
\hline & \multicolumn{2}{c}{ Keay } & \multicolumn{2}{c}{ Asa } \\
\hline ha & $\%$ & (Sample) & $\%$ & (Sample) \\
\hline $0-0.9$ & 19.4 & $(6)$ & 13.6 & $(3)$ \\
\hline $1-1.9$ & 58.1 & $(18)$ & 40.9 & $(9)$ \\
\hline $2-2.9$ & 16.1 & $(5)$ & 27.3 & $(6)$ \\
\hline $3-3.9$ & 3.2 & $(1)$ & 4.5 & $(1)$ \\
\hline $4-4.9$ & 3.2 & $(1)$ & 0.0 & $(0)$ \\
\hline 5 or more & 0.0 & $(0)$ & 0.0 & $(0)$ \\
Up to 8.9 & & & & \\
\hline $9-9.9$ & 0.0 & $(0)$ & 4.5 & $(1)$ \\
\hline $10-10.9$ & 0.0 & $(0)$ & 4.5 & $(1)$ \\
\hline $11-11.9$ & 0.0 & $(0)$ & 4.5 & $(1)$ \\
\hline Total & 100.0 & $(31)$ & 100.0 & $(22)$ \\
\hline
\end{tabular}

Note: Rubber fields which have not yet been harvested are not counted. Source: Field research

very rare. This led us to conclude that the cash income differential among villagers caused social disruption. Meanwhile the breakdown of the social safety net and the decline in the philosophy of mutual aid caused by the livelihood pattern change and increasing cash income also in a way encouraged poor villagers' feelings of unfairness and jealousy, which led to social disruption.

\section{Latter stage of expanding phase: Asa Village Technology and Economy}

About half of the households in Asa have discontinued swidden (Table 11), and some villagers practice swidden not to grow rice, but to cultivate rubber fields. It is possible for villagers to make a living with cash income from rubber, as in Keay.

The living standard in Asa is as high as in Keay because most villagers have motorbikes, and most children can attend high school. We inferred that there are differences in annual cash income among households because of the differential in harvestable rubber field ownership (Table 12) ${ }^{(22)}$. Major rubber field holders are increasing their holdings by purchasing land from other villagers, and they are using fertilizers, agrochemicals, and weeding machines.

\footnotetext{
(22) The cash income differential is evident from data on differences in rubber field ownership. According to research results on Keay, the factors for determining the amount of income from rubber production are: (1) the number of rubber fields owned that can already be harvested, (2) the diligence applied to management and harvesting, and (3) whether the villager has another source of cash income. The reason there is no difference between the number of rubber fields owned by the middle-income group and the number owned by the highincome group in Keay is in the early stage of expansion. When Keay enters the latter stage of expansion, it is likely that large rubber field holders will emerge through purchases of land from villages like Asa.
}

\section{Work organization and Values}

We inferred that individual family labor has increased and opportunities for collaborative work have decreased as in Keay. Rubber field holdings per household have increased, but these rubber fields are tapped by family labor. A few households use Betusa' with relatives as in Keay.

Some large-scale rubber holders hire several workers as Betusa' ${ }^{(23)}$. Larger-scale rubber holders complained about the equal-division system of Betusa' with rubber because the cost of raising and maintaining a rubber field is higher than with rattan.

There are many costs associated with raising and managing rubber fields. The costs consist of buying land and paying workers to clear rubber tree undergrowth. Owners pay for fertilizers and agrochemicals even if workers harvest gum as Betusa'. In the case of rattan, there is no cost associated with managing rattan gardens. In addition, the period of employment of Betusa' for rubber is longer than for rattan. There is no strict term of employment for working times and amount of harvest, so workers can work freely as if the rubber fields were their own. This means that if workers do not tap rubber trees diligently, owners lose benefits over a long period of time. For the reasons mentioned above, large rubber field holders complained about the equal-division system, become selective about workers, and fire idle workers to recover costs ${ }^{(24)}$. But they themselves think it is difficult to change the equal-division system because of its long history. They also fear worsening their relationships with villagers due to hiring and firing of workers thoughtlessly ${ }^{(25)}$.

Related problems include the stealing of gum, which is occurring in Asa as in Keay. In addition, some workers occasionally report the amount of harvested gum falsely, or do not report it all.

These are signs that the equal-division system of Betusa' is changing and that the philosophy of mutual aid based on the feeling of Terasi, which makes it possible for all villagers to work via Betusa', is becoming unstable.

\footnotetext{
${ }^{(23)}$ One large-scale rubber holder who has 11 ha of rubber fields hires 11 workers.

${ }^{(24)}$ Those hired are honest people who do not report harvests falsely, disciplined people who tap rubber trees punctually, and skilled people who do not injure rubber trees.

${ }^{(25)}$ But there are already some instances in which workers who did not tap diligently were fired.
} 
Table 13. Summary of changing factors in cultural ecosystems of Benuaq society in each cultivation phase ${ }^{1}$.

\begin{tabular}{|c|c|c|}
\hline & Cultural ecosystems based on Sw/RtPd & Cultural ecosystems based on Sw/RbPd \\
\hline $\begin{array}{r}\text { Phase } \\
\text { (site) }\end{array}$ & $\begin{array}{l}\text { Before introduction of } \\
\text { rubber (Besiq, JD) })^{2}\end{array}$ & $\begin{array}{l}\text { Latter stage of expansion } \\
\text { (Asa) }\end{array}$ \\
\hline Technology & $\begin{array}{l}\text { Sw for rice } \\
\text { RtPd }\end{array}$ & $\Rightarrow \quad$ Sw for rubber field \\
\hline Factors & $\begin{array}{c}\text { Sw } \\
\text { RtPd } \\
\text { RbPd: success or not }\end{array}$ & $\begin{array}{l}\text { Deceasing } \mathrm{Sw} \\
\text { Sw for rubber field } \\
\mathrm{RbPd}\end{array}$ \\
\hline Economy & $\begin{array}{c}\text { Low-income } \\
\text { High self-sufficiency }\end{array}$ & $\begin{array}{l}\text { High-income and income differential } \\
\text { Low self-sufficiency }\end{array}$ \\
\hline Factors & $\begin{array}{l}\text { Low income from rattan } \\
\text { Rice : HSS }\end{array}$ & $\begin{array}{l}\text { High income from rubber } \\
\text { Income gap } \\
\text { Rice : LSS }\end{array}$ \\
\hline $\begin{array}{c}\text { Work } \\
\text { organization }\end{array}$ & $\begin{array}{l}\text { Collabolative works } \\
\text { profit-sharing system }\end{array}$ & $\begin{array}{c}\text { Individual work } \\
\text { private-profit system }\end{array}$ \\
\hline Factors & $\begin{array}{l}\text { Sw: Kerja edotn, Pelo } \\
\text { RtPd: Kerja edotn, } \\
\qquad \text { Betusa' } \\
\text { RtPc:Gosok }\end{array}$ & $\begin{array}{l}\text { Sw:Kerja edotn, Upaah, } \\
\text { Decreasing Pelo } \\
\text { RbPd: Kerja edotn, Betusa' } \\
\text { RbPc: } \times\end{array}$ \\
\hline Values & Philosophy of mutual aid: Stable & Philosophy of mutual aid: Unstable \\
\hline Factors & $\begin{array}{l}\text { Dividing harvests, } \\
\text { Interdependent } \\
\text { relationship }\end{array}$ & $\begin{array}{l}\text { Complaints over dividing system; } \\
\text { Selection of workers in Betusa'; } \\
\text { Stealing, False reports }\end{array}$ \\
\hline
\end{tabular}

Note1: Meaning of abbreviations: JD=jengan danum, $\mathrm{Sw}=$ swidden, RtPd=rattan production, RtPc= rattan processing, $\mathrm{RbPd}=$ rubber production, $\mathrm{RbPc}=$ rubber processing, HSS=high self-sufficiency, LSS=low self-sufficiency.

Note 2: Factors were arranged using the information in Inoue (1989)

Source: Prepared by Daisuke Terauchi based on field research data and Inoue (1989).

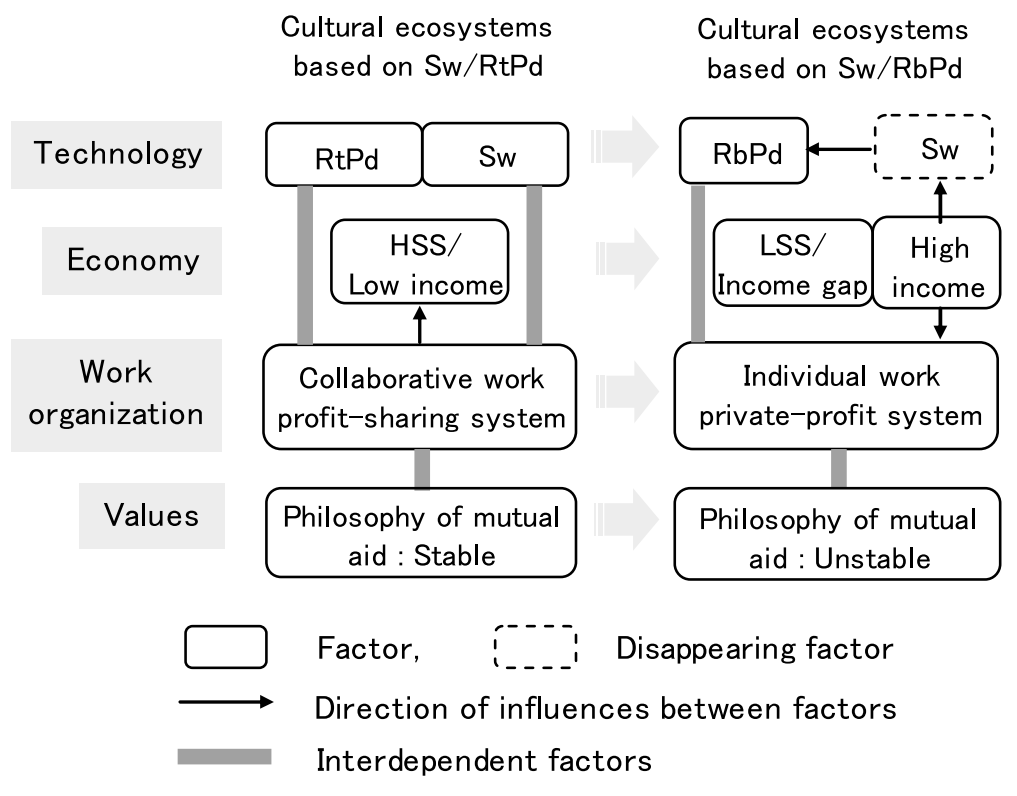

Fig.3. Changes in cultural ecosystems. Source: Prepared by Daisuke Terauchi 


\section{Summary of changing factors in each village}

Table 13 summarizes the changing factors in cultural ecosystems in each phase (research site). In the technology section, swidden (Sw) for rice and rattan production (RtPd) changed to swidden for rubber fields and rubber production ( $\mathrm{RbPd}$ ). In the economy section, low income and high self-sufficiency rate changed to high income, low self-sufficiency rate, and unequal income. In the work organization types and values section, collaborative work and profit-sharing systems changed to individual work and a private-profit system ${ }^{(26)}$. The philosophy of mutual aid became unstable.

\section{CONCLUSIONS}

\section{Cultural ecosystem based on swidden-rattan production}

Household economies were not good in cases where livelihood was based on swidden and rattan production because the price of rattan was stagnating. The rate of rice self-sufficiency was very high, and villagers were looking for other jobs such as selling the meat from wild animals or paid labor in Betukng, except harvesting rattan, to raise cash income. Various types of work organization, such as Pelo and Konokng in swidden, and Betusa' and Gosok in rattan production, were adopted along with cooperative hunting. These collaborative work types and profit-sharing systems played an important role in their livelihood as a social safety net. Because these work organization types were supported by a philosophy of mutual aid, as in Terasi, all villagers could join them.

Rubber trees as an external factor were planted in the fallow season. Rubber field management requires much more labor than rattan, and hence competition for labor arose between the management of rubber fields and swidden. In addition, villagers were not used to intensive management, and rubber tree seedlings were damaged by wild animals. Some villagers were unsuccessful in raising rubber fields.

\footnotetext{
${ }^{(26)}$ In this paper, the work organization types based on a philosophy of mutual aid such as Pelo, Konokng, Betusa', Gosok and cooperative hunting are called the "collaborative work and profit-sharing system." Other work organization types such as Kerja Edotn are called the "individual work and private-profit system." It is difficult to judge whether Upaah is based on philosophy of mutual aid or not, because Upaah is adopted to Konokng and Betusa', while some villagers criticized Upaah as philosophy of individualism/selfish, comparing to Pelo.
}

\section{Cultural ecosystem based on swidden-rubber production}

After gum harvesting started, annual cash income increased and villagers made a living with cash income from rubber. Half of the villagers discontinued swidden, while others practiced swidden in order to raise rubber fields. Thus the rate of rice self-sufficiency declined. Additionally, cash-income differentials emerged among villagers. Betusa' in relatives' rubber fields played an important role for the low income households as a social safety net. But this situation was rare because there were not enough rubber fields needing Betusa' and the easy tapping operation was carried out by individual family labor. In addition, there is no processing process involved in rubber production. There were fewer opportunities for Pelo and Konokng because of decreasing swidden. Collaborative work and the profit-sharing system changed to individual work and a private-profits system. Therefore the social safety net based on collaborative work began to malfunction ${ }^{(27)}$. In swidden, villagers who have money did not join Pelo, instead using Upaah. This demonstrates that the philosophy of mutual aid had weakened ${ }^{(28)}$.

We inferred that the villagers' feelings of unfairness and jealousy caused by cash income differentials among villagers led social disruption. Meanwhile the breakdown of the social safety net and the decline in the philosophy of mutual aid caused by the change in livelihood patterns and increasing cash income also encouraged the villagers' feelings of unfairness and jealousy, which led to social disruption.

\footnotetext{
(27) It is likely that there are social safety nets in other sectors of society, as well as in work organization sectors. For example, there is a custom in Benuaq society in which villagers who have hunted wild animals give the meat to neighbors or relatives. This is called mirikng. There is another custom, called sake, in which villagers ask for meat from wild animal. But these daily mutual-aid activities are also weakened by the infiltration of the market economy. Some villagers have started selling meat from wild pigs in town, instead of giving it to people. Since then, villagers have become hesitant to ask for meat because asking for meat is now equivalent to asking for money. A villager who asks for meat is thus regarded to be poor.

${ }^{(28)}$ We don't conclude that villagers' values shift from philosophy of mutual aid to philosophy of individualism/selfishness, but philosophy of mutual aid was weakened in Keay, comparing to Betukng. Upaah might also be based on philosophy of mutual aid between swidden owner and worker, similar to Betusa' and Konokng. And we think people have both philosophy of mutual aid and individualism/selfishness and both philosophies are conflicting each other in every occasion. We have to notice that we got this conclusion as a result of the discussion on only the values in work organization, not yet discuss about values in other aspects.
} 


\section{Perspectives on cultural ecosystem}

Some large rubber field holders emerged and hired several villagers as Betusa' workers. The rubber harvest Betusa' system was the same as that of the rattan harvest. But some large rubber holders complained about the equal-division system of Betusa' because the cost of raising and managing rubber fields was high. Owners became selective in hiring and firing idle workers. The philosophy of mutual aid based on feelings of Terasi, which makes it possible for all villagers to work and derive cash income from Betusa', appears to have become unstable.

\section{RECOMMENDATIONS}

It is said that rubber production from trees can be continued for 35 years (Penot 2004). It has been recognized that if villagers reuse the rubber fields as swidden fields, the swidden and rubber production system is a sustainable system in the sense of maintaining a long-term cycle of swidden and generating cash income in fallow periods just as the swidden and rattan production system does.

Rubber fields can be divided into two types: those like secondary forest in Betukng, and those like the plantation in Keay. They can be established not only in mature forest but also on degraded land. Depending on the combination of the rubber field type and the condition of the land, growing rubber might result in not only forest degradation as in Betukng because of changes from old secondary forest to rubber fields, but also forest restoration as in Keay because of changes from degraded land to rubber fields. Rubber agroforestry offers the possibility of achieving both environmental and economic improvement as in Keay. Therefore the important issues are the combination of the kind of rubber field established and the condition of the land in conjunction with the socioeconomic context, such as population density and the swidden land-use pattern. There is a need to promote research into efficient agroforestry techniques for villagers who face constraints on capital and labor, as suggested by Penot (2004), to improve economic conditions while maintaining the environment, and to adapt to increasing population and the uncertainty of the global market economy.

Further attention should be paid to social issues as well as environmental, technical, and economic issues. This paper demonstrated that the change of livelihood patterns and increasing cash income from the introduction of rubber production simplified the various types of work organization which played the role of social safety net, thereby undermining the philosophy of mutual aid. These changes are not good for the stability of local society. Regarding social aspects, it is important to maintain the philosophy of mutual aid and construct a new collaborative work and profit-sharing system for social ties, which were maintained under the conditions of a self-sufficient economy. But it is not an easy task and not sufficient to adapt to the conditions of the market economy. It is likely that selfish thinking will become increasingly stronger, and that villagers' lives will be exposed to the risks of the market economy under conditions of the market economy. It is therefore important that villagers try to construct a new social safety net in cooperation with government, such as an institutional system for redistributing wealth among villagers and decreasing market economy risk.

It is important to simultaneously advance efficient agroforestry techniques for environmental and economic improvements, and to maintain the complexity of social ties for the well-balanced development of swidden society. It is also necessary to try to establish a new institutional social safety net in cooperation with government to adapt to market economy conditions.

ACKNOWLEDGMENTS This research has been supported by a 21 st Century COE Programs of The University of Tokyo, ÒBiodiversity and Ecosystem RestorationÓ (headed by WASHITANI Izumi), Grant in Aid for Scientific Research on Priority Areas, ÒManagement of local commons in the globalization eraÓ (headed by MUROTA Takeshi, No.18078009), and Grant in Aid for Scientific Research (A), ÒConditions for developing collaborative governance of forests in accordance with the localityO (Headed by INOUE Makoto, No. 19208014).

\section{REFERENCES}

Angelsen, A. 1995. Swidden and ÒDeforestationÓ: A study from Indonesia. World Development 23: 1713-1729.

Asian Development Bank. 2002. Project completion report on the Tree Crop Smallholder Sector Project (Loan 1118-INO) in Indonesia. July 2002.

Balow, C. \& Jayasuriya, S.K. 1984. Problems of investment for technical advance: The case of 
Indonesian smallholders. Bulletin of Indonesian Economic Studies 35: 85-95.

Balow, C. \& Muharminto. 1982. The rubber smallholder economy. Bulletin of Indonesian Economic Studies 18: $86-84$.

de Jong, W. 2001. The impact of rubber on the forest landscape in Borneo. In: Agricultural technologies and tropical deforestation (eds. A. Angelsen, D. Kaimowitz), pp. 367-381, CABI Publishing, Wallingford, Oxon, UK.

DEPARTEMEN PERTANIAN (DP). 1994. Petunjuk Tehnis Usaha Tani Budidaya Tanaman Karet. Direktorat Jenderal Perkebunan Proyek Pengembangan Budidaya Perkebunan Rakyat, ABD, Jakarta. 54 pp.

Dove, M.R. 1993. Smallholder rubber and swidden agriculture in Borneo: A sustainable adaptation to the ecology and economy of the tropical forest. Economic Botany 47: 136-147.

Gouyon, A., Foresta, H.D. \& Levang, P. 1993. Does 'jungle rubber' deserve its name? An analysis of rubber agroforestry systems in southeast Sumatra. Agroforestry System 22: 181-206.

Hukao, Y. 2004. Socioecological Transformation Triggered by National Rubber Plantations in Yunnan, China: The Impact of Han-Chinese Immigration into Xishuangbanna since the 1950s. Southeast Asia Studies 42: 294-327.

Hukui, K. 1994. The permanence of nature: the culturization of succession and wildfire in swidden and livestock farming (in Japanese). In: Lecture on living on the Earth. Socialization of nature 2: The perception of nature in subsistence (in Japanese). (eds. Kakeya, M.), pp. 115-142. Yuzankaku, Tokyo.

Inoue, M. 1995. Swidden and tropical rainforest: The changing of the traditional swidden system in Kalimantan (in Japanese). 176pp. Kobundo.

Inoue, M. 1990. Changes in the Swidden System of the Kenyah Dayak Tribe. Southeast Asia Studies 28: 222-255.

Inoue, M. 1990. The system of swidden and rattan production in East Kalimantan, Indonesia. (in Japanese). Journal of Forest Economics 119: 43-50.

Inoue, M. 1989. Section 2 The Dayak Benuaq villages. In: Swidden cultivation in East Kalimantan. pp.70-91. The Tropical Rain Forest Research Project JTA 9 (a)-137 Japan International Cooperation Agency.

Kawakita, J. 1989. Environment and culture. In: Environmental science II, The system of human society (in Japanese). (eds. Kawamura, T. \&
Takahara, S), pp.1-33. Asakura Publishing Co., Ltd., Tokyo.

Miyamoto, M. 2006. The relationship between Forest Conversion and Inequality of Land Ownership, and the Factors Responsible for Increasing the Inequality in Sumatran Rubber Villages, Indonesia. Journal of Japanese Forestry Society 88: 70-86.

Pambudhi, F., Belcher, B., Levang, P. and Dewi, S. 2004. Rattan (Calamus spp.) gardens of Kalimantan: resilience and evolution in a managed non-timber forest product system. In: Forest Products, Livelihoods and Conservation: Case Studies of NonTimber Forest Product Systems Volume 1-Asia. (eds. Kusters, K. \& Brian, B.), pp. 337-354. Center for International Forestry Research.

Pelzer, K.J. 1978. Swidden cultivation in Southeast Asia: historical, ecological, and economic perspectives. In: Farmers in the forest: Economic development and marginal agriculture in northern Thailand (ed. Kunstadter, P.), pp. 271-286. East-West Center, Honolulu.

Penot, E. 2004. From shifting agriculture to sustainable complex rubber agroforestry systems (jungle rubber) in Indonesia: a history of innovation processes. In: Beyond Tropical Deforestation from tropical deforestation to forest cover dynamics and forest development (ed. Babin, D.), pp. 221-249. The United Nations Educational, Scientific and Cultural Organization (UNESCO) and Le Centre de coopŽration internationale en recherche agronomique pour le dŽveloppement (CIRAD).

Sato, R. 1999. Current Trends in Studies of Swidden Agriculture in the Tropics: Ecological Aspect and Historical Context. Japanese Journal of human geography 51: 47-67.

Thomas, K.D. 1965. Swidden and production of small holder rubber in a South Sumatran village. Malayan Economics Review 10: 100-115.

Vicent, J.R. \& Hadi, Y. 1993. Malaysia. In: Sustainable Agriculture and the Environment in the Humid Tropics (eds. National Research Council), pp. 440-482. National Academy Press. Washington. DC.

Watanabe, H. 2002. Tropical Forest Conservation and NonTimber Forest Products (in Japanese). Kyoto University Press. 287 pp.

Weinstock, J.A. 1983. Rattan: Ecological Balance in a Borneo Rainforest. Economic Botany 37: 58-68.

Received $29^{\text {th }}$ Sep. 2009

Accepted $21^{\text {st }}$ Oct. 2010 
